\title{
The Place of e-Astuteness and e-Social Astuteness in e-Skills Policy-making in South Africa
}

\author{
Zoran Mitrovic \\ University of the Western Cape, Bellville, South Africa
}

zmitrovic@uwc.ac.za

Mymoena Sharif

iKamva National e-Skills Institute, Pretoria, South Africa

mymoena@doc.gov.za

Wallace Taylor

The Information Society Institute, Cape Town, South Africa

wallace.j.taylor@gmail.com

\begin{abstract}
Material published as part of this publication, either on-line or in print, is copyrighted by the Informing Science Institute. Permission to make digital or paper copy of part or all of these works for personal or classroom use is granted without fee provided that the copies are not made or distributed for profit or commercial advantage AND that copies 1) bear this notice in full and 2) give the full citation on the first page. It is permissible to abstract these works so long as credit is given. To copy in all other cases or to republish or to post on a server or to redistribute to lists requires specific permission and payment of a fee. Contact Publisher@InformingScience.org to request redistribution permission.
\end{abstract}

The development of the Internet and other information and communication technologies (ICT) in recent decades represents a material foundation for a networked society, which requires profoundly new ways of thinking, working and living, including building of new capacities for the entire nation. In that regard, South Africa (SA) needs a new approach to ICT skilling ('eskilling') in order to achieve a positive impact on meeting the national goals and aspirations. It was recently concluded at some relevant gatherings in SA that some social and "intuition" related skills ("soft" skills) needed to be included in the e-skilling agenda, if the majority of citizens were to be successfully included in the emerging Knowledge Society. Hence, SA e-Skills Institute introduced the concepts of "astute" use of e-skills for personal growth and self-reliance (eAstuteness) and collective development through use of ICT (e-Social Astuteness) into its strategic plans. However, to this point it was not clear how the concept of e-Astuteness and e-Social Astuteness relate to the e-skills policy- making framework in South Africa. Thus, we set an objective of exploring the fit of these still novel concepts into the SA e-Skills Policy-making Framework. Utilising approach of theory development, this paper attempts to give answer to that ques-

tion by suggesting that the concepts of e-Astuteness and e-Social Astuteness are cross-cutting throughout several elements of this framework. It is envisaged that this study will benefit e-skills policy-makers, practitioners and researchers who would, hopefully, advance our work. 
Keywords: ICT, e-skills, policy-making, e-Astuteness, e-Social Astuteness, South Africa.

\section{Introduction}

The development of the Internet and other information and communication technologies (ICT) in recent decades represents a material foundation for a networked society and the emergence of new economies (frequently referred to as "Knowledge Society") and is now directly affecting individuals and whole societies. ICT is regarded as an indisputable component of addressing the major issues of equity, sustainability and global competitiveness. Knowledge Society, being still in its early developmental phase in many developing countries (such as South Africa), requires profoundly new ways of thinking, working and living, which includes building of new capacities for the entire nation. These capacities are inter alia inevitably associated with use of ICT and are often referred to as e-skills, which are broadly described as the ability to develop and use ICT to adequately participate in an environment increasingly dominated by access to electronically enabled information and a well-developed ability to synthesise this into effective and relevant knowledge. E-skills are particularly important in developing countries as a base for achieving sustainable development goals (IDRC, 2008) as all credible evaluations of most suitable approaches for overcoming poverty and inequity point to the necessity and effective appropriating of ICT into local socio-economic circumstances (OECD, 2005; Spence \& Smith, 2010; World Bank, 2012).

In order to address a considerable deficiency in e-skills (estimated shortage of 70.000 e-skilled professionals and many more ICT unskilled citizens), the South African government through the Department of Communication (DoC) has established the e-Skills Institute (e-SI) with the mandate to concentrate on the development of adequate skills to allow its citizens to improve their capacities of using all forms of ICT at work, in their education, personal lives and governance. In this regard, the e-SI is also responsible for creating appropriate policies which should be linked to other relevant national (e.g., Medium Term Strategic Framework (MTSF), 2009 - 2014) and international (e.g., UN Millennium Development Goals - MDGs) developmental strategies.

The 2nd South African e-Skills Summit (Cape Town, October 2012), jointly held with the International Telecommunication Union's (ITU) Global ICT Forum on Human Capital Development, provided the e-SI and various e-skills stakeholders (business, government, education, organised labour, civil society organisations) and the international partners (e.g., UNDP, ITU, CISCO) concluded that a new approach to 'e-skilling' was needed to achieve a positive impact on meeting the goals and aspirations of South Africa's strategic plans. Furthermore, it was recognised that in order to meet the stated targets of achieving an e-literate society by 2030 , formal education and training could not be the sole basis of an e-skilling agenda. It was also concluded that some social and intuition related skills ("soft" skills) needed to be included in the e-skilling agenda, if the majority of citizens were to successfully apply e-skills in their everyday lives. Hence, the e-Skills Institute introduced a concept of "astute" use of e-skills for personal growth and self-reliance (eAstuteness) into its strategic plans. On the other hand, there is a need for a socially astute use of ICT for developing collective capability to harness modern forms of ICT in a cohesive manner. It is suggested (Mitrovic et al., 2013) that this can be achieved through the concept of e-Social Astuteness as a mean for developing capability across the full spectrum of society that would allow individuals and collectives to harness ICT for individual or group benefits. In a nutshell, eAstuteness and e-Social Astuteness skills can be considered as "smart ways" to apply the required e-skills for more equitable personal and communal socio-economic development.

Deemed as very important, e-Astuteness and e-Social Astuteness skills have been included into the National e-Skills Pan of Action (NeSPA, 2013) and the National Integrated ICT Policy (NICTP, 2014). However, to this point it was not clear how the concept of e-Astuteness and eSocial Astuteness can be used for e-skills policy-making, i.e. what would be the conceptual fit of 
these concepts into the e-skills policy- making frameworks in South Africa (SA). Hence, we set objectives of exploring the fit of these still novel concepts into SA skills policy -making frameworks and produce a conceptual model that can explain and guide this match.

\section{Approach to this Study}

In order to meet the established objectives, we first explored available e-skills frameworks in South Africa in order to identify the most suitable one for this study. Our search, however, returned only one relevant policy-making framework (Sharif, 2013). We then explored relevant policy-making frameworks coming from different contexts (e.g., DAE, 2013) but could not find much relevance to our study. Hence, we decided to use Sharif's framework for this research. We then explored available literature on the topic of e-Astuteness and e-Social Astuteness and again find only one relevant study, by Mitrovic et al. (2013). The search for use of e-Astuteness and eSocial Astuteness skills in either developed or developing countries context did not return any useful result, showing that these two concepts are truly novel.

We, subsequently, compared these two studies in order to establish possible connection between them and produce a conceptual model to help in identifying the place and fit of e-Astuteness and e-Social Astuteness into the e-skill policy-making framework in SA.

The overall aim of this study is theory building around the fit of these two concepts into existing e-skills policy framework (Sharif, 2013). We based this study on the premise that, "theory embodies statements of the knowledge that has been developed by humanity in a form that has both use in the practical world where human beings act based on their knowledge (partly learned from theories) and in the theoretical world where researchers validate or refute old knowledge and build new knowledge in the form of theories" (Venable, 2006). Since theory building includes "development of new ideas and concepts" (Nunamaker et al., 1991), the approach of this study was to understand how concepts of e-Astuteness and e-Social Astuteness could contribute to more effective e-skills policy-making, hence influencing more effective socio-economic appropriation of ICT, for more equitable development at personal and societal/communal levels in South Africa.

Generally, this paper aims to provide a conceptual basis for defining the fit of novel skills of eAstuteness and e-Social Astuteness into the e-skills policy-making framework, which can be used for practical policy-making in this area. Such policies can support the appropriation of emerging ICT capability, mobility, accessibility and affordability that at the outset favours 'smarter' developed economies which have higher levels of embedded use and understanding, but still lags in developing economies. We are, however, aware that the absence of greater number of e- skills policy-making frameworks in South Africa (or elsewhere) and non-existence of work on eAstuteness and e-Social Astuteness inevitably limits generalization of our findings but we still believe that this study can benefit e-skills policy-makers, practitioners and researchers, who would, we hope, advance our work.

This paper proceeds with explaining e-Skills Policy-making Framework in South Africa, depicting concepts of e-Astuteness and e-Social Astuteness, followed by mapping these concepts into the e-skilling framework. The paper ends with the answer to the question of how e-Astuteness and e-Social Astuteness fit into the e-skills policy-making framework in SA.

\section{E-Skills Policy-making Framework in South Africa}

The e-skills framework related to the South African contextual policy-making was developed by Sharif (2013) (Figure 1) and, according to our research, it is the only currently available framework of this kind. This framework is based on the premise that the development of e-skills should not happen in isolation if we are to effectively proceed from a socially excluded e-society to an e- 
inclusive one. The reviewed literature suggest a range of approaches in that regard: from the use of Sen's (1992) Capability Approach or Van Dijk's (2012) relational or network approach to Nash's (2011) approach. All these approaches show that digital inclusion requires a broader approach, since ICT are not so much hierarchical as they are non-linear; the social behaviours are more networked and act upon the realms of social and digital exclusion. This suggests that the eskills agenda should be more than rolling out ICT and ICT skills (e-skills) to people. It has to be a deliberative process targeted at unpacking digital and social exclusion, within the South African context in this case, and to develop strategies and policies that address issues around capability deprivation. Whatever strategies and policies are put in place, there is a need to focus on capabilities of using ICT in ways relevant to development priorities: "When ICT strategies and policies are in place, a limited investment in human and technological capabilities can have an enduring, catalytic effect on development concerns, including poverty, gender inequalities, and the environment" (Tella \& Olorunfemi, 2010). E-skills are important drivers of digital inclusion since "to be effective a smart, sustainable growth strategy must also be inclusive so that all are given the opportunities and skills to participate fully in an Internet-enabled society" (European Commission, 2012, p. 1).

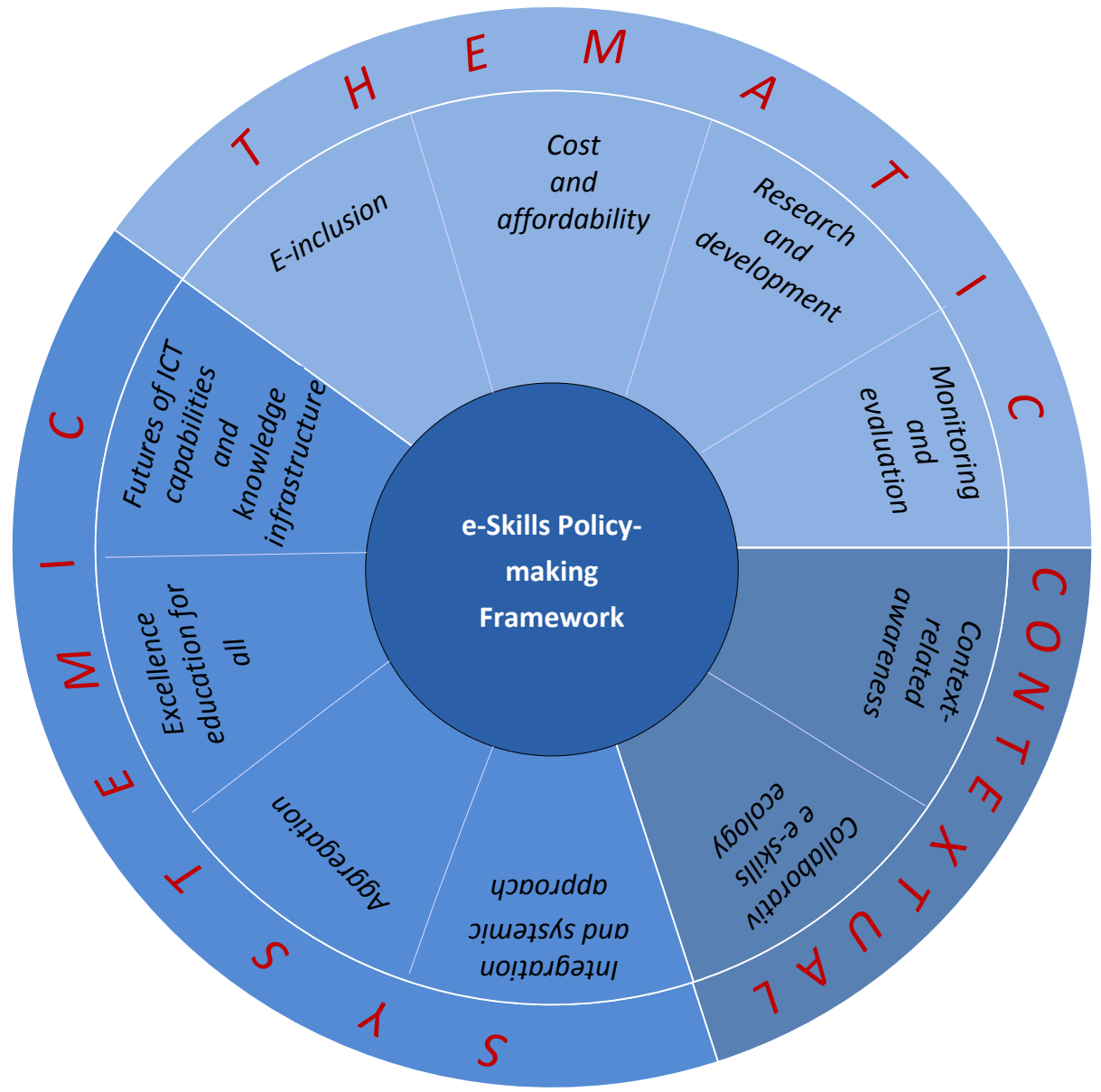

Figure 1: Proposed e-skills policy-making framework in South Africa (source: Sharif, 2013)

Sharif (2013) explains that e-skilling is context-related and requires the right data to know how the stages of e-skills development will impact the context issues suggesting that e-skills solutions for South Africa cannot be replicated from the more developed countries. Sharif argues that those solutions largely revolve around 'practitioner' (professional) e-skills, while countries like South Africa are constraint by huge social and economic disparities, massive illiteracy and considerable 
"digital divide". Hence, e-skills policy creation should take into consideration (i) internationally recognised e-skills frameworks such as SFIA (2013) or EeCF (2013), and (ii) local (SA) research in this area that adds new value. Subsequently, Sharif (2013) proposed the e-skills policy-making framework for South Africa having the following elements grouped into three conceptual clusters.

The Thematic cluster of the policy-making framework elements suggests that the e-skills policies can include any relevant theme or topic but should be primarily concerned about:

- E-Inclusion: as a prerequisite for building already emerging Knowledge Society;

- Cost and affordability: as these factors can hinder use of ICT and development of eskills;

- Research and development as it is a crucial for further e-skills development (e.g. determining demand and provision); and

- Monitoring and evaluation: as it is indispensable to determine if an e-skills intervention generates the planned output, outcome and impact.

The Contextual cluster of the policy-making framework elements suggest:

- Context-related awareness is needed to establish and influence of, for example: (i) awareness of the ways in which ICT can be used in everyday life and work; (ii) awareness of ICT access and availability; (iii) awareness of ICT impact and benefits; or (iv) awareness of the needed e-skills and how to acquire them;

- Collaborative e-skills ecology as it suggest participation in e-skills policy-making of "contextual" or national, provincial or local stakeholders: (i) major stakeholders groups such as governments, businesses, education or civil society organisations; and (ii) minor stakeholders groups such as people with disabilities or the groups at risk of social exclusion (e.g. immigrants, homeless people).

The Systemic cluster of the policy-making framework suggests that:

- Integration and systemic approach, which includes integrated and collaborative work within and across government, the private sector, education and civil society, is essential in South Africa to develop a Knowledge Society and achieve more equal development and global competitiveness. This element also suggests that e-skills policy-making should support national, provincial and/or local socio-economic developmental plans, programmes or agendas.

- Aggregation is needed to concentrate resources, efforts and results in order to achieve socio-economic impact, which essentially e-skills policies should support. This element of e-skills policy-making framework supports the idea that "in silo" or "patched" approach will not succeed.

- Excellence education for all is indispensable for appropriate e-skills development and the use of ICT for socio-economic appropriation. This kind of education must be systemically addressed through the educational systems.

- Futures of ICT capabilities and knowledge infrastructure bears significance in the facts that, for e-skilling, it is highly important to identify future appropriate ICT that can affect social and economic progress. The knowledge obtained through the collaborative networks (knowledge infrastructure) is inter alia important for continued reassessment of the skills that people already have over what they need. 


\section{Concepts of e-Astuteness and e-Social Astuteness}

This section is solely based on work of Mitrovic et al. (2013) as it was only available article on the topic of e-Astuteness and e-Social Astuteness. Since these concepts are rather novel, we believe that they deserve explanation in more detail.

\section{e-Astuteness}

The concept of an astute use of ICT aligned to the general concept of e-skills is not unique to the South African thinking as it appears that other countries (developed and developing) also favour this idea (Mitrovic et al., 2013). For example, the European ICT Standards Board emphasised the importance of an astute use of ICT and information for decision making in the "world economy in new millennium" (ICTSB, 2012). The Government of Hong Kong is also advising its top-ranking universities to deliver "astute ICT personnel", which are in a short supply but are dearly needed in the knowledge-based society and economy (Ho, 2012). The government of Thailand, through the ICT Policy Framework (ICT2020, 2011) states "for the civil servants and/or general staff, skills should be developed in using basic ICT in a smart way, with good judgement and astuteness". Even some schools have realised the importance of an astute use of ICT aligned to the general concept of e-skills by asserting that their "students will learn to become independent and astute users of ICT' (TEC, 2012).

Although there is no commonly accepted definition of astuteness, there is an agreement that the term refers to an intellectual capacity that "emerges at the crossroads between mind and culture" (Parales-Quenza, 2006). The concept of astuteness also refers to the skill of planning to achieve goals, mainly in political or business situations (Perrewe et al., 2000). It is significant that astuteness is not deemed as a personality construct or a psychopathological category but as a functional, adaptive intelligent capacity fuelled by sociocultural conditions (Parales-Quenza, 2006). Astuteness is a skill that can be learned and deployed in "situations involving diverse and sometimes competing interests and stakeholders, in order to create sufficient alignment of interests and/or consent in order to achieve outcomes" (Alford et al., 2012). In summary, astuteness is by Mitrovic et al. (2013) defined as an intellectual capacity, based on personal and interpersonal skills, that involves 'reading' people and situations, building alignment and alliances (networks), acute understanding of a strategic direction and applying strategic behaviour that allows individuals to take personal advantage of a situation.

It is significant from an e-skills perspective that the pertinent literature also refers to "technological astuteness" which is characterised by creating a mind-set that embraces all forms of technology and prepares users for future forms of technology and their possible applications (Caron \& Stasko, 2010). As it was deemed this term is defined rather broadly and does not allow for easy operationalization within an e-skills construct, Mitrovic et al. (2013) describe e-Astuteness as a concept that involves "a knowledgeable capacity, based on personal and interpersonal skills, that inter alia involves understanding of the emerging capacity of ICT devices relevant to local applications, people and situations, building alignment and alliances (networks), acute understanding of strategic direction and applying strategic behaviour that allows individuals to take personal advantage of the use of ICT through appropriate e-skills in the social (e.g. building social connections), service delivery (making the best use of ICT enabled services as users), education (formal and informal) or economic (e.g. obtaining job or starting own business) situations". They also stressed that the concept of e-astuteness outlined by them is not necessarily predicated on formal education or high levels of literacy. 


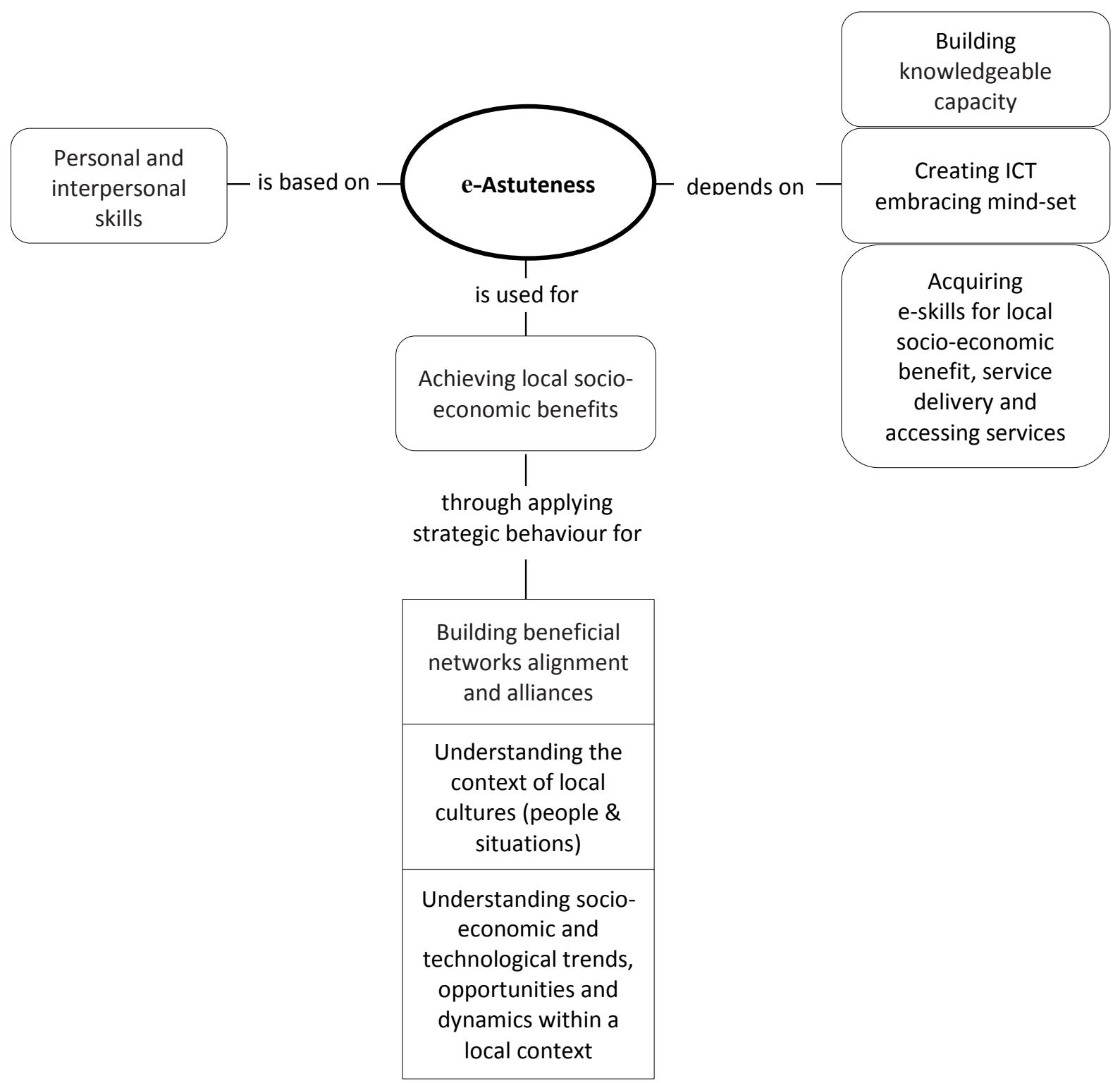

Figure 2: Conceptual model of e-Astuteness (source: Mitrovic et al., 2013)

According to the authors, e-Astuteness is a dependent construct (Figure 2), which is based on personal and interpersonal skills of individuals and is reliant on building a knowledgeable capacity and creating a mind-set that embraces all forms of technology and prepares users for future forms of technology and their possible socio-economic applications. E-Astuteness can help individuals (i) to understand people (local cultures) and situations better, (ii) to build beneficial alignment and alliances (networks - local, national and international - personal, learning, business and services) and (iii) towards better understanding of the current strategic socio-economic and technological directions within local applicability. Also, the concept of e-Astuteness assumes that individuals should possess certain e-skills so that they can apply both operational and strategic behaviour in the use of modern ICT for achieving individual socio-economic benefits (Mitrovic et al., 2013). 


\section{e-Social Astuteness}

The pertinent literature does not provide much about the concept of Social Astuteness except in the context of political skills. Ferris et al. (2005) discuss Social Astuteness within four dimensions of political skills: (i) networking ability, (ii) interpersonal influence, (iii) social astuteness, and (iv) apparent sincerity. Many authors believe that (i) the ability to 'read' and understand people, and (ii) being able to act on that knowledge in influential ways are two dimensions reflecting on Social Astuteness (Mintzberg, 1983; Pfeffer, 1981; Ferris et al., 2005). Social Astuteness can be also strongly related to self-monitoring, attending to details (conscientiousness) and political savvy (Snyder, 1987). Notions of "savvy" in general, and "political savvy" in particular, as noted by Ferris et al., (2005), make reference to a degree of understanding that is closely related to the Social Astuteness. Mitrovic et al. (2013) favour a definition of Social Astuteness that refers to "more astute ways of people interacting with others, including social interactions, levels of awareness and understanding diverse social situations and the various alternatives open to them for a collective positive response to changed circumstances". Accordingly, they define e-Social Astuteness as "the use of ICT and e-skills for more astute ways of people interacting with others for a collective socio-economic benefit". This is related to a process of (i) involvement in a network of social interactions, (ii) having a collective level of awareness and understanding diverse social situations, (iii) the identification of socio-economic needs and opportunities that could be met with ICT enabled applications, (iv) the examination of various alternatives, (v) the development, testing and modification of options, (vi) the assessment of 'fit' of value proposition i.e. success or failure and applicability and (vii) network supported adoption and scaling (Mitrovic et al., 2013).

It has also been explained by the authors of this concept that astute social networks can leverage new levels of awareness and understanding of diverse social and economic situations, and can lead to the identification of new alternatives to address local socio-economic issues (Figure 3). The benefits from utilising e-Social Astuteness are primarily related to community networked action but this does not exclude individual effort. 


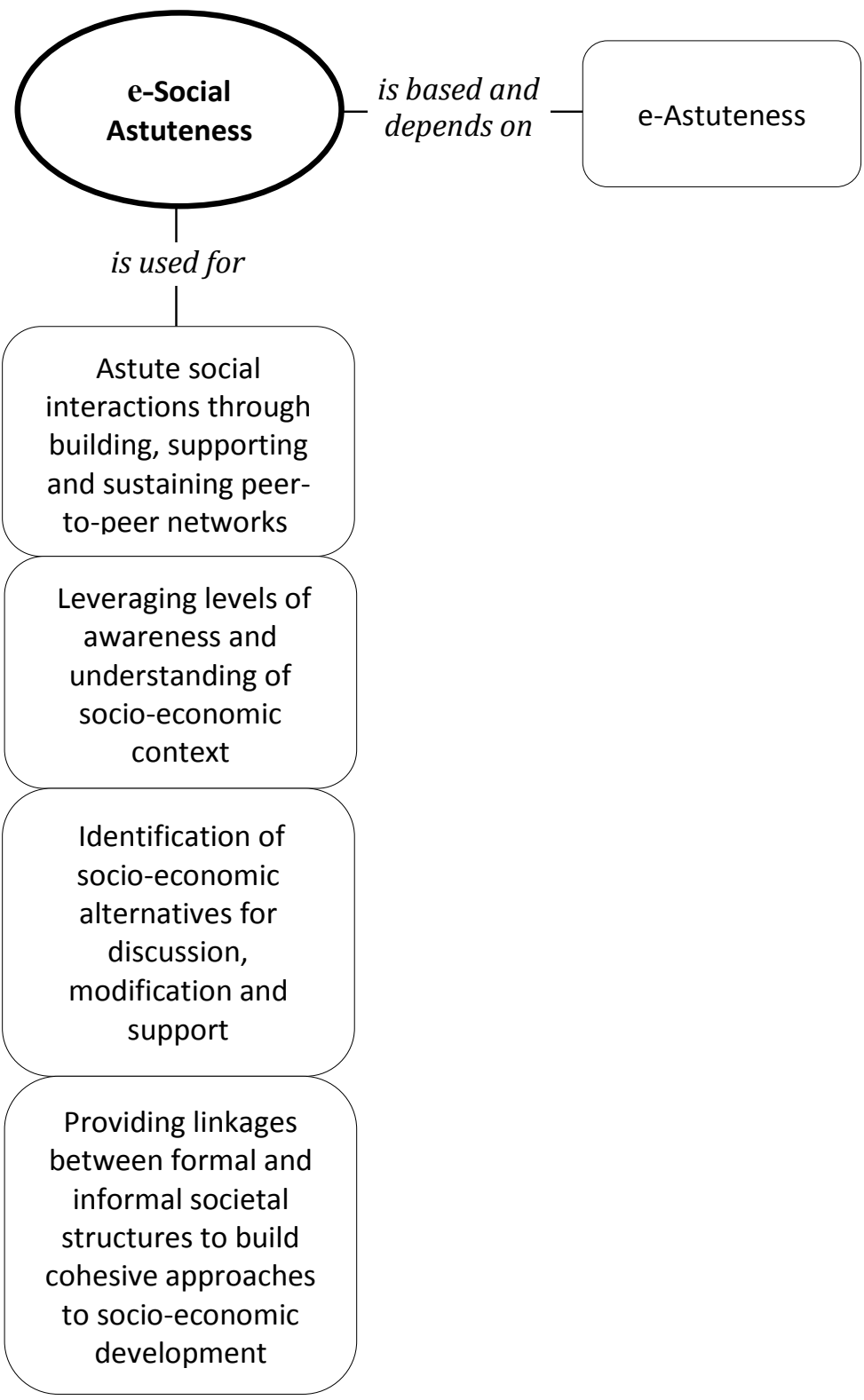

Figure 3: Conceptual model of e-Social Astuteness (source Mitrovic et al., 2013)

\section{Conceptual Fit: The place of e-Astuteness and e-Social Astuteness in e-Skills Policy-making in South Africa}

Achieving the outlined objective of this study, i.e., identifying the conceptual place of eAstuteness and e-Social Astuteness within the SA e-Skills Policy-making framework, required a possible mapping these two concepts to the framework's appropriate areas. That mapping disclosed that six of the then framework's element can be in some way linked to development and use of e-Astuteness or e-Social Astuteness or both - as pictured in Table 1 and Figure 4. 
Table 1: Mapping e-Astuteness and e-Social Astuteness to e-Skills Policy-making Framework (source: Authors)

\begin{tabular}{|c|c|c|}
\hline $\begin{array}{l}\text { Elements of e-Skills Policy- } \\
\text { making Framework }\end{array}$ & e-Astuteness & e-Social Astuteness \\
\hline E-inclusion & $\begin{array}{l}\text { - Creating ICT embracing mind- } \\
\text { set; } \\
\text { - Building beneficial network } \\
\text { alignment and alliances. }\end{array}$ & $\begin{array}{l}\text { Astute social interactions through } \\
\text { building, supporting and sustaining } \\
\text { peer-to-peer networks. }\end{array}$ \\
\hline Cost and affordability & $\mathrm{n} / \mathrm{a}$ & $\mathrm{n} / \mathrm{a}$ \\
\hline Research and development & & $\mathrm{n} / \mathrm{a}$ \\
\hline Monitoring and evaluation & $\mathrm{n} / \mathrm{a}$ & $\mathrm{n} / \mathrm{a}$ \\
\hline Context-related awareness & $\begin{array}{l}\text { Understanding the context of local } \\
\text { culture (people \& situations). }\end{array}$ & $\begin{array}{l}\text { - Leveraging level of awareness } \\
\text { and understanding of socio- } \\
\text { economic context; } \\
\text { - Identification of socio-economic } \\
\text { alternatives for discussion, modi- } \\
\text { fication and support. }\end{array}$ \\
\hline $\begin{array}{l}\text { Collaborative e-skills ecol- } \\
\text { ogy }\end{array}$ & $\begin{array}{l}\text { Developing personal and interper- } \\
\text { sonal skills. }\end{array}$ & $\begin{array}{l}\text { Acquiring and applying personal and } \\
\text { interpersonal skills through ICT ena- } \\
\text { bled social networks. }\end{array}$ \\
\hline $\begin{array}{l}\text { Integration and systemic } \\
\text { approach }\end{array}$ & & $\begin{array}{l}\text { Providing linkages between formal } \\
\text { and informal societal structures to } \\
\text { build cohesive approaches to socio- } \\
\text { economic development. }\end{array}$ \\
\hline Aggregation & $\mathrm{n} / \mathrm{a}$ & $\mathrm{n} / \mathrm{a}$ \\
\hline $\begin{array}{l}\text { Excellence education for } \\
\text { all }\end{array}$ & Building knowledge capacity. & $\begin{array}{l}\text { Building collective knowledge capaci- } \\
\text { ty. }\end{array}$ \\
\hline $\begin{array}{l}\text { Futures of ICT capabilities } \\
\text { and knowledge infrastruc- } \\
\text { ture }\end{array}$ & $\begin{array}{l}\text { Understanding socio-economic } \\
\text { and social trends, opportunities } \\
\text { and dynamics within the local con- } \\
\text { text. }\end{array}$ & $n / a$ \\
\hline
\end{tabular}

\section{E-Inclusion}

Creating ICT embracing mind-set is a foundation for digital inclusion of people that are not exposed to modern technologies. E-Astuteness helps in overcoming fear of "unknown" technologies and facilitate "discovery" of usefulness of these technologies. On the other hand, e-Social Astuteness, results from social interactions through appropriating modern ICT within cultural and socioeconomic development and also supports these interactions through peer-to-peer networks. This implies that the capacity to transcend individual expectations and intentions to include them in a network of social relations (developing social capital and cohesion) inter alia results from transforming e-Astuteness to e-Social Astuteness. 


\section{Context-related Awareness}

Developed awareness and understanding of practical and strategic opportunities in the local socio-economic context, together with appropriate behaviour, allows individuals to take personal advantage of the use of modern ICT devices in their own socio-economic situations (eAstuteness). Interpersonal influence and networking abilities can help individuals to adapt their behaviour according to each particular situation, allowing different targets of influence in ranges of contextual conditions to be developed for both personal and community goals. This can lead to the identification of socio-economic alternatives for discussion, modification and application for individual and community advancement.

\section{Collaborative E-skills Ecology}

Collaborative e-skills ecology provides an environment in which individuals will be able to develop personal and interpersonal skills for astute use of modern ICT (e-Astuteness) and also enables acquisition, modification and use of e-skills through ICT enabled social networks. So called "best-practice countries" have understood a role of collaborative e-skills ecology, which provides a solid base of ICT technical skills as well as highly developed adoption of ICT across business, education, service delivery and social uptake as consumers, communities and families.

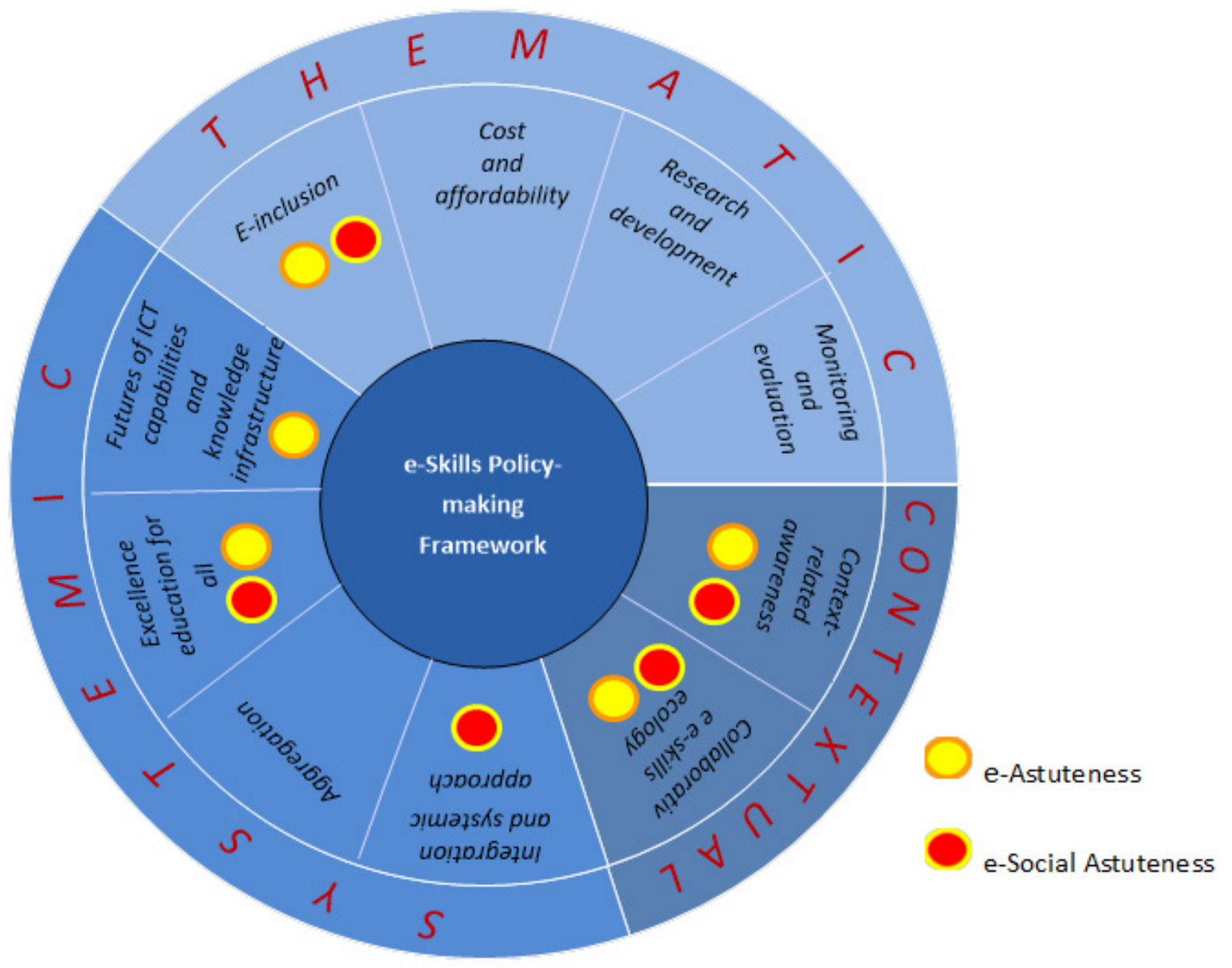

Figure 4: The Places of e-Astuteness and e-Social Astuteness in e-Skills Policy-making Framework (source: Authors, based on Sharif, 2013) 


\section{Integration and Systemic Approach}

Integrative and systemic approach to e-skilling is enabler that provides linkages between various stakeholders (e.g. business, government, academia, civil society) and also between formal and informal societal structures thus helping to build cohesive approaches to socio-economic development. Skills required within the labour market, starting a business, developing and using ICT enabled service delivery, education and local socio-economic development require astuteness in communication skills, team work, collaboration, critical thinking, decision making and general social skills. In environments that are increasingly dominated by modern ICT e-Astuteness and eSocial Astuteness are vital in understanding strategic and practical environmental implications and applying relevant strategies and praxis to the ICT-enabled socio-economic development.

\section{Excellence Education for All and Futures of ICT Capabilities and Knowledge Infrastructures}

Globalizing economy requires workers, learners and civil society consumers who are astutely able to perform complex tasks and adapt rapidly to a changing environment and the evolving needs of the economy which is increasingly dominated by new forms of ICT. Well-developed understanding of both practical and strategic opportunities and applying appropriate behaviour (i.e., astuteness) allows individuals to take personal advantage of the use of modern ICT devices in their own socio-economic situations. It is well-known that "best-practice countries" have developed solid base of ICT technical skills as well as highly developed adoption of ICT across business, education, service delivery and social uptake as consumers, communities and families. Creating an e-Astuteness and an e-Social Astuteness mind-set that embraces all forms of technology and prepares users for future forms of technology and their possible applications provides countries, businesses, education, governments and civil society with significant advantage. Most digital skills are not the result of computer courses, but of learning of how to apply modern ICT in local situations and with non-technical applications in real life situations i.e. e-Astuteness and e-Social Astuteness. This also implies certain understanding of socio-economic and social trends, opportunities and dynamics within the local context as well as (at least) to some extent the futures of ICT capabilities and knowledge infrastructures.

\section{Conclusion}

Meeting the objective of this study, i.e., exploring the conceptual fit of still novel concepts of eAstuteness and e-Social Astuteness into the e-Skills Policy-making Framework in South Africa, we concluded that these concepts are not mere additions to the existing elements of the proposed South African e-skills policy-making framework (Sharif, 2013). Instead, these concepts are crosscutting throughout several elements of this framework, giving them a considerable significance. As much as a well-defined e-skills policy-making framework is essential for guiding development of digital skills for $21^{\text {st }}$ century, the concepts of e-Astuteness and e-Social Astuteness are "perceived to be needed for building an inclusive economy and in developing leadership to work together at the local level to solve socio-economic problems" (Mitrovic et al., 2013).

It is here important to state that there are two distinctive ways how people think and act about their own (human) condition (Garner, 2012, pp. 11-12): (i) stay in the status quo position and consolidate what they have and (ii) discovering of what is still possible to achieve and opening up considerations of how much it can be achieved. We here advocate the latter approach by suggesting that inclusion of e-Astuteness and e-Social Astuteness into e-skills policy-making framework fosters a "path of discovery to appropriate modern ICT into a social construct that can unite people in a common purpose to address inequity" (Mitrovic et al., 2013). We strongly believe that achieving a society that offers a more equitable prosperity and a more inclusive economy, there is 
a need for committed people across the full spectrum of society who understand how to best appropriate ICT into personal and community benefits.

However, it is also important to state that theoretically derived conceptual fit do not guarantee practical usefulness and automatic application of models such as one pictured in this study. Although essential, understanding the theoretical and contextual background is only one of factors that influence "real life" policy-making. It is indicative that research is most frequently used to legitimate policy decisions rather than to inform policy formulation processes (Jones et al., 2008) -and this is particularly true for developing countries such as South Africa. Studies show that many policy processes are only weakly informed by the research evidence (Bird et al., 2005). It is often argued that the knowledge gained by research, instead of being used for informing policies, is often isolated from the policy-makers and practitioners in the field (e.g. Hearn \& White 2009). Hence, we believe that success in these matters, in the developmental context, is very much dependent on government leadership in establishing enabling policy-making environment, which will consider research evidence. Furthermore, we recommend inclusion of e-Astuteness and eSocial Astuteness in e-skills policy-framework in South Africa, cautioning that the current context and changes that might occur in the socio-economic or technology arenas must be considered in this regard.

We also do acknowledge some limitations of this study of which one is the absence of greater number of e-skills policy-making frameworks in South Africa and elsewhere, and non-existence of work on e-Astuteness and e-Social Astuteness, which inevitably limits generalization of our findings. In addition, since this is only theoretical study about inclusion of rather novel concepts in e-skills policy-making, we recommend that this model be empirically tested in order to prove its validity. However, despite certain limitations, we still believe that this study can be of use by e-skills policy-makers and researchers, who can advance our work.

\section{References}

Alford, J., Hartley, J., \& Hughes, O. (2012). Political astuteness as an aid to discerning and creating public value. Conference on Creating Public Value in a Shared-Power, Multi-Sector World Centre for Integrative Leadership, University of Minnesota, 20-22 September 2012.

Bird, K., \& Pratt, N. with T. O’Neil \& V. Bolt. (2004). Fracture points in social policies for chronic poverty reduction. ODI Working Paper 242. London: ODI

Caron, P., \& Stasko, D. (2010). Technological astuteness: Preparing student teachers for the digital classroom. In D. Gibson \& B. Dodge (Eds.), Proceedings of Society for Information Technology \& Teacher Education International Conference 2010 (pp. 3993-4000). Chesapeake, VA: AACE

DAE. (2013). Policy Making 3.0. Digital Agenda for Europe. Retrieved 8 April 2013 from https://ec.europa.eu/digital-agenda/en/policy-making-30-0

EeCF. (2013). European e-Competence Framework. Available at: www.ecompetences.eu/

European Commission. (2010). The European Platform against Poverty and Social Exclusion: A European framework for social and territorial cohesion. Brussels: European Commission.

Ferris, G. R., Treadway, D. C., Kolodinsky, R. W., Hochwarter, W. A., Kacmar, C. J., Douglas, C. \& Frink, D. D. (2005). Development and validation of the political skill inventory. Journal of Management, 31, $126-152$.

Garner, E. (2012). Maximising your potential. Bookboon.com. Available at http://books.google.co.za/books?id=EAKKso5nVbEC\&printsec $=$ frontcover $\# \mathrm{v}=$ onepage $\& q \& \mathrm{f}=$ false

Hearn, S., \& White, N. (2009). Communities of practice: Linking knowledge, policy and practice. The Overseas Development Institute (ODI), UK. Retrieved 12 February 2010, from http://www.odi.org.uk/resources/download/1129.pdf 
Ho, S. (2012). Opening remarks by Miss Susie Ho, JP, Permanent Secretary for Commerce and Economic Development (Communications and Technology) at the "IT Man Workshop. Office of the Government Chief Information Officer, The Government of Hong Kong Special Administrative Region. Retrieved on 4 January 2013 from www.ogcio.gov.hk/en/news_and_publications/speeches/2012/12/sp_20121212.htm

ICT2020. (2011). Thailand Policy Framework (2011-2020): ICT 2020. Ministry of Information and Communication Technology, May 2011. Retrieved on 22 August 2012 from http://unpan1.un.org/intradoc/groups/public/documents/ungc/unpan048145 1.pdf

ICTSB. (2012). ICT Standardisation, ICT Standards Board. Retrieved on 6 January 2013 from www.ictsb.org/about/ICT_standardization.htm.

IDRC. (2008). ICT's for sustainable development. Available at: www.idrc.ca/en/ev-1-201-1DO TOPIC.html

ITU-Summit. (2012). Summit conclusions. $2^{\text {nd }}$ e-Skills Summit and the International Telecommunication Union (ITU) Global ICT Forum on Human Capital Development, 22-25 October 2013, Cape Town. Unpublished.

Jones, N., Jones, H., \& Walsh, C. (2008). Political science? Strengthening science-Policy dialogue in developing countries. Working Paper 294. London: ODI.

Mintzberg, H. (1983). Power in and around organizations. Englewood Cliffs, NJ: Prentice Hall.

Mitrovic, Z., Taylor, W. Sharif, M., Claassen, W., \& Wesso, H. (2013). E-Social astuteness skills for ICTsupported equitable prosperity and a capable developmental state in South Africa. International Journal of Education and Development using ICT, 9(3).

Nash, P. (2011). E-participation: Looking beyond skills and realising public value. European Journal of ePractice, 12(March/April).

NeSPA. (2013). National e-Skills Plan of Action (NeSPA): Continuing e-skilling the nation for equitable prosperity and global competitiveness. Pretoria: Department of Communications: e-Skills Institute.

NICTP. (2014). National integrated ICT policy. Green Paper. Government Gazette, 583(37261). Pretoria, 24 January.

Nunamaker, J. F., Jr., Chen, M., \& Purdin, T. D. M. (1991). Systems development in information systems research. Journal of Management Information Systems, 7 (3 Winter 1990-1991), 89-106.

OECD. (2005). Good practice paper on ICTs for economic growth and poverty reduction. The DAC Journal, 6(3).

Parales-Quenza, C. J. (2006). Astuteness, trust, and social intelligence. Journal for the Theory of Social Behaviour, 36, 1,39-56.

Perrewé, P. (2013). Distinguished Research Professor, Management. The Florida State University. Retrieved on 14 January 2013 from www.fsu.edu/profiles/perrewe/

Pfeffer, J. (1981). Power in organizations. Boston: Pitman.

Sen, A. K. (1992). Inequality re-examined. Oxford: Clarendon Press.

SFIA. (2013). Skills Framework for the Information Age. Available at: www.sfia-online.org/

Sharif, M. (2013). A framework for e-skills policy-making in South Africa. Masters Thesis, Department of Information Systems, University of the Western Cape. Unpublished.

Snyder, M. (1987). Public appearances, private realities: The psychology of self-monitoring. New York: Freeman.

Spence, R., \& Smith, M. L. (2010). ICT, development, and poverty reduction: Five emerging stories. USC Annenberg School for Communication \& Journalism, 6, Special Edition 2010, 11-17.

TEC. (2012). Key Stage 4 ICT. Tamorth Enterprise College, UK. Retrieved on 27 October 2012 from www.belgrave.staffs.sch.uk/page/?title=Key+Stage+4+ICT\&pid=43 
Tella, A., \&Olorunfemi, D. Y.O. (2010). The future of ICT in developing world: Forecasts on sustainable solutions for global development. India Journal of Library and Information Science, 4(2), MayAugust.

Van Dijk, J. A. G. M. (2012). The evolution of the digital divide: The digital divide turns to inequality of skills and usage. In J. Bus et al. (Eds), Digital Enlightenment Yearbook, 2012, IOS Press.

Venable, J. (2006). The role of theory and theorising in design science research. In S. Chatterjee \& A. Hevner (Eds.), Proceedings of the First International Conference on Design Science in Information Systems and Technology. DESRIST 2006, Claremont, pp. 1-18.

World Bank. (2012). ICT for greater development impact. World Bank Group Strategy for Information and Communication Technology, 2012-2015, June 15, 2012.

\section{Biographies}

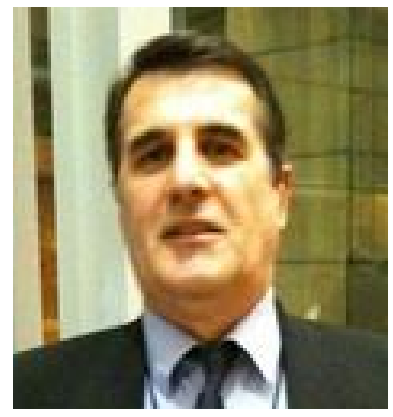

Dr Zoran Mitrovic is the Coordinator of the Masters in Information Management Programme at the University of the Western Cape, South Africa. He is the leading author of the South African National e-Skills Plans of Action (NeSPA 2010 and NeSPA 2013). His research and consulting praxis encompasses the development of e-skills in the developmental context, the use of ICT for local socio-economic development, e-government policies and praxis, and the use of ICT for sustainability development.

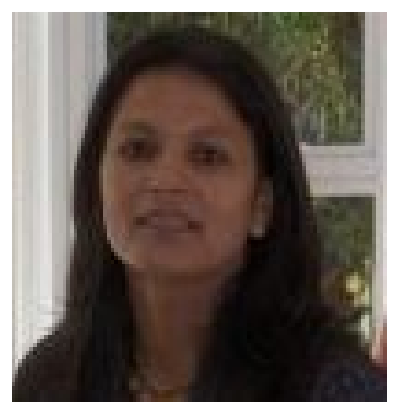

Mymoena Sharif is the Chief Director of the Department of Communications iKamva National e-Skills Institute, a South African government initiative to advance and implement key e-skills interventions. She is a member of the Strategic Council for the United Nations Global Alliance on ICT for Development and is a former winner of the Bill \& Melinda Gates International Access to Learning Award. She is coauthor of the South African National e-Skills Plans of Action (NeSPA 2010 and NeSPA 2013).

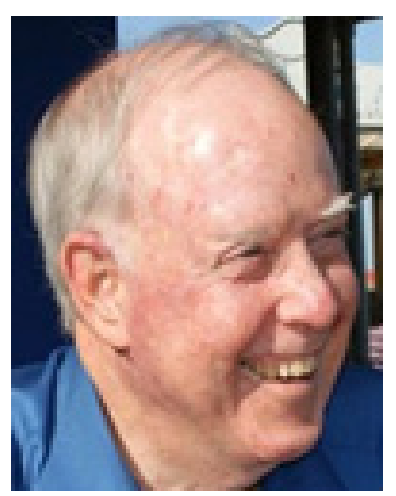

Prof Wallace Taylor is the founding director of The Information Society Institute (TISI), which is currently engaged with the South African Department of Communications e-Skills Institute in addressing national and international issues involved in the social appropriation of ICT for local socio-economic benefits. Prof Taylor is also Honorary Professor the University of the West Indies. His current research and praxis interests are focussed on the social appropriation of ICT, public policy development, the role of higher education in the information society and building self-reliance for civil society inclusion. Prof Taylor was named as Citizen of the Year by the City of Rockhampton (Australia) in 2001 for his contribution to community development, the initiation of a range of community and industry events, organisations and programmes. He is co-author of the South African National e-Skills Plans of Action (NeSPA 2010 and NeSPA 2013). 